\title{
Има ли библиотекара у библиотекама?
}

\author{
Драгана Сабовљев \\ Градска народна библиотека „Жарко Зрењанин“, Зрењанин \\ dragana.sabovljev@gmail.com
}

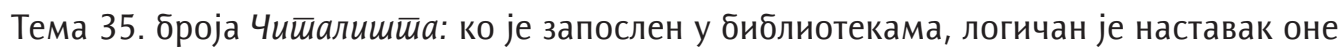
из мајског броја, о стручним звањима у библиотечко-информационој делатности. Такође је наставак и теме Библиотекарство у Србији: законодавни оквир и пракса (бр. 29, новембар 2016), али и оне из далеке 2010 (бр. 16, мај), о високошколском образовању библиотекара. Овај низ, који се бави болном тачком струке - професионализацијом кадра запосленог у библиотекама, говори заправо о великом броју нерешених питања која се понављају сада већ деценијама: Ко ради у библиотекама? Које професије су најзаступљеније? Који профили запослених из читаве палете нових занимања би били пожељни за даље унапређење библиотечко-информационе делатности? Питања нерационалног запошљавања, као и подједнако нерационалне забране запошљавања, задиру већ у неке друге теме које није било могуће отворити, јер би изашле из оквира научног приступа и зашле у поље дневне политике.

Тако, Тему овог броја Чишалишйа чине три рада. Анђела Стошић и Ана Ђорђевић урадиле су анализу образовне структуре запослених у јавним библиотекама Србије. Ауторке - докторанткиње на Катедри за библиотекарство и информатику Филолошког факултета Универзитета у Београду - пружиле су нам, са једне стране, охрабрујући податак да тренутно највећи број библиотекара има високу стручну спрему, а са друге, да је од тога тек нешто више од 10\% дипломираних библиотекара. Прецизније - библиотекара који су формално образовање стекли на катедрама у Београду и Сомбору, пошто су, по Закону о библиотечко-информационој делатности, дипломирани библиотекари сви они који положе стручни испит у Народној библиотеци Србије и/или Библиотеци Матице српске - нема разлике. Још више би, међутим, требало да уплаши податак о поразно малом броју младих људи који се запошљавају у библиотекама. Уз највеће поштовање према кадру средњих година који је професију унапредио у претходних неколико деценија, поставља се питање коме пренети своја знања и искуства.

Следи чланак Карле Селихар и Жељка Вучковића о Катедри за библиотекарство на Педагошком факултету у Сомбору, који описује њен наставни програм, али, много значајније, говори о бризи предавача о могућностима запослења академских грађана које образују.

Желећи да прикажемо и тренутно стање у региону, обратили смо се Саши Мадацком са Универзитета у Сарајеву. Добили смо рад о кадровској политици транзиционог библиотекарства на Балкану, приказаној кроз призму стратегије Међународне федерације библиотечких асоцијација и установа за период 2019-2024, заснован на теорији „магијског реализма" и подацима из истраживања стања библиотека основних и средњих школа у Кантону Сарајево. Потпуно нетипично за његове духовите написе - успео је да нас растужи.

Можда нисмо довољно јасно одговорили на питање ко ради у библиотекама у Републици Србији и Босни и Херцеговини, али смо дошли до закључка о томе ко не ради - они који су се школовали за занимање које сви толико волимо и којем смо толико посвећени. Они, нажалост, одлазе у иностранство или раде у call центрима. 